\title{
The Potential of Poverty in the City of Palangka Raya: Study SMIs Affected Pandemic Covid 19
}

\author{
Pipit Anggriati Ningrum ${ }^{1}$, Alexandra Hukom², Saputra Adiwijaya ${ }^{3}$ \\ ${ }^{1}$ Postgraduate Program in Economy Sciences, Universitas Palangka Raya and Penyuluh pada Dinas \\ Perdagangan dan Perindustrian Provinsi Kalimantan Tengah \\ ${ }^{2}$ Department of Development Economics, Faculty of Economics, Universitas Palangka Raya \\ ${ }^{3}$ Faculty of Social Science and Political Science, Palangka Raya University and Kepala Pusat Studi \\ Kebijakan Publik LPPM \\ phietningrum0205@gmail.com
}

\begin{abstract}
This study aims to analyze the increasing potential for poverty in the city of Palangka Raya from the perspective of SMIs due to the impact of the 19th COVID pandemic. The data was obtained based on the results of in-depth interviews from February to April 2020 with 10 SMIs and supported from secondary data from the Central Statistics Agency. The data is processed based on qualitative research principles based on the type of case study research. In the results of this study it was found that the SMIs experienced a very detrimental impact in terms of sales and marketing of products so that employees who come to work are terminated indefinitely, in this connection it appears that there is potential increases in poverty that can occur in the future come.
\end{abstract}

Keywords

Poverty, covid 19; SMs, Palangka Raya

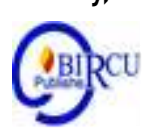

\section{Introduction}

Since the outbreak of the corona virus that was recorded starting at the end of 2019 in China, precisely the city of Wuhan, then later this virus became global and infected almost all countries in the world including Indonesia. The world health agency (WHO) has also announced that the corona virus, also called COVID-19, is a global threat worldwide.

The outbreak of this virus has an impact especially on the economy of a nation and globally. This unforeseen circumstances automatically revised a scenario that was arranged in predicting an increase in the global economy. In the online media daily jeo insight.kompas.com dated March 23, 2020 in mentioning the international monetary institution (IMF) also said that global economic growth was predicted to slow down, thus revising the projections of world economic growth for this year, since the corona plague hit. Whereas before, in January 2020, the IMF projected that global economic growth would strengthen, from 2.9 percent in 2019 to 3.3 percent in 2020.

The impact caused by this virus also approached Indonesia and its entire region, including in the city of Palangka Raya, the capital of Central Kalimantan Province. There is a great potential that has an impact on poverty when outbreaks which until now have not found anti-virus.

While in other parts of the business that developed in communities that rely on creativity and self-reliance in the form of SMIs (Small and Medium Industries) are also affected. Small and Medium Industries (SMIs) in the year before the beginning of the reform marked by the global financial crisis is considered as the pillar of the nation's economy and is considered a form of business that can withstand a wide range of issues during the pandemic COVID turns 19, was devastated. Of the various forms of business 
that exist instead of going bankrupt, when moving businesses can not even fully cover the needs of businesses and daily needs. Some of the aid program is regarded as a relaxation of the situation is also not provide assurance of the continuity of a SMIs that developed in the community, especially the city of Palangkaraya. And if the previous period to the SMIs sector is able to absorb significant workforce as one of the efforts in poverty alleviation.

This condition may lead to new problems that there is the potential for hidden poverty which could later surge when the Covid 19 pandemic ends, and when reversing it to normal conditions if a misstep will make the nation worse off. It takes a short amount of time when then returning to its original state and of course added with a variety of new problems.

\section{Review of Literatures}

Issues of poverty and inequality are interrelated with limitations in all respects to access from available resources, so then the discussion about poverty becomes very varied and not solely viewed from an economic standpoint, and each expert will give a different review.

By Levitan (1980) in Warsono et al (2011) provide an opinion that poverty as a lack of goods and services needed to achieve a decent standard of living. Then in another part according to Schiller (1979) poverty is the inability to get goods and services that are adequate to meet limited social needs.

Another opinion that also states about poverty can be seen according to Baidhawy (2015), quoting from Kerbo (1996) identifying four kinds of theories of poverty. First is Darwinian social theory. This theory first appeared in sociology and tried to explain poverty in terms of the behavior and attitudes of the poor themselves. Poor people are poor because they don't work hard, they use money to gamble, get drunk and get unnecessary luxury and they also have a chaotic family life. They have no ambition, no inner calling to work, are fatalistic and suffer from lack of education.

Second is the culture of poverty. This theory was developed by Oscar Lewis, an anthropologist. He developed this theory from his experience in Mexico. Culture of poverty is a special syndrome that grows in a number of situations. This culture requires a cash economy setting, namely high unemployment and underemployment, low wages and people with low skills. In the absence of support from voluntary or state institutions and stable families, low-income populations tend to develop a culture of poverty to oppose the ideology of accumulation that is dominant among the middle class. The poor state that they have a marginal position in a structured and individualistic capitalistic society, which offers them nothing for prospects for upward mobility. In order to survive, they must develop their own institutions and agencies because the wider community tends to ignore and leave them. So, the poor try to form their own set of values, norms, and behavior patterns that are different from general culture.

Third is the theory of situational poverty. This theory believes that poor people behave differently because they do not have the resources and opportunities to imitate middle class lifestyles. Young people have few opportunities to go to college and they drop out a lot. Women prefer matrifocal families because they allow them to claim their children. This theory emphasizes the importance of structural conditions that produce poverty, but this theory also tends to focus on individual responses to the objective situation of poverty. This theory is fundamentally different from the cultural theory of poverty. This theory does not assume the existence of subcultures that give rise to coherence and solidity in the behavior of the poor. Situational theory states that individuals rationally follow behavioral patterns that 
are appropriate to the objective situation in their lives. Poor people don't follow middle class values because they know they can't do it.

Fourth is structural poverty theory. This theory believes that poverty is caused by a wider socio-economic structure. Namely is the macro structure of society that gave birth to inequality and poverty as a result. The structure of global capitalism, for example, creates gaps and poverty on a wide scale throughout the world. Marxism with its various variants maintains the perspective of this theory. The theory of dependency which is arose in Latin America, specifically attention to third world poverty. The theory of marginalization from Latin America has a rich tradition of exploring the fate of human deprivation and marginality.

\section{Research Methods}

This study used a qualitative research method with a case study approach to ten SMIs who were affected during the COVID 19 pandemic. This research is based on the time between February-April 2020. Case study approach according to Ary in Idrus (2009) as an intensive investigation of an individual, but case studies can also be used to investigate small social units such as families, schools, or groups.

Then to test the validity of the data obtained so that it is truly in accordance with the aims and objectives of the study, the researchers used triangulation techniques. According to Moleong (2007) states that data triangulation is a data checking technique that utilizes something other than the data for checking or comparison purposes.

Whereas for data analysis researchers are guided by the interactive technique of Miles and Huberman in Sugiyono (2008) that the activities in qualitative data analysis are carried out interactively and continue continuously until completion, so that the data is already saturated. Activities in data analysis are data reduction, data display, and conclusion drawing / verification.

\subsection{Data of Palangkaraya City}

In connection with the theme of this study the following supporting data are presented in the city of Palangka Raya, the figures in this data are based on secondary data obtained from the Central Bureau of Statistics of the city of Palangka Raya in 2019.

\subsection{Total of Population}

Based on the results of the 2010-2020 population projection, the population of Palangkaraya City in 2019 reached 291,667 people. Consisting of male population of 149,489 people (51.25 percent) and female population of 142,178 people (48.75 percent). Compared to the previous year, there was an increase of 8,055 people or by 2.84 percent in 2019 .

\subsection{Employment Labor Force Participation Rate (TPAK) and Open Unemployment Rate (TPT)}

In the period 2017 to 2019, the Labor Force Participation Rate (TPAK) of Palangka Raya City had the highest value in 2019 with a percentage of 64.45 percent. TPAK also increased in 2018 to 62.99 . This value indicates that out of 100 population aged 15 years and over, there are 64 to 65 people who are in the labor force (working and unemployed). When compared to the Central Kalimantan TPAK, the Palangkaraya TPAK is lower from year to year. This is because in Palangka Raya is an education center so many students / students outside the area are school in Palangka Raya. Students 15 years old and above increase the proportion of Non-Workforce (BAK), so that Palangkaraya TPAK is relatively smaller. The Open Unemployment Rate (TPT) of Palangka Raya City is relatively greater than the Central 
Kalimantan TPT in the period 2017 to 2019 even in the range of more than 5 percent in the period 2017 to 2019 namely 7.26 percent, 5.81 percent and 5.78 percent. Palangkaraya TPT which is higher than other regencies / cities in Central Kalimantan was triggered by its status as provincial capital.

Then in 2019 recorded the majority of unemployed people with high school education and above and the most unemployed are vocational education (SMK). Most unemployment in Palangkaraya City is unemployed with the last level of education completed by SMK by 10.10 percent followed by unemployed with an elementary school level of 7.82 percent. Meanwhile in the province of Central Kalimantan, the highest TPT in 2019 was found in graduates Vocational School and High School.

Then when viewed from the Business Field and Employment Status in 2019, a total of 129,914 residents of Palangka Raya are employed, most or around 59.82 percent work as laborers / employees / employees. Workers with the status of self-employed around 18.58 percent, self-employed assisted by non-permanent / unpaid workers / around 8.35 percent, and assisted by permanent / paid workers around 4.20 percent. Meanwhile, there are 6.28 percent of family workers / unpaid. The population works as free labor in agriculture and non-agriculture by 2.77 percent.

\subsection{Total of Poor People}

The poor population in Palangka Raya shows its development the smaller the percentage. The government continues to press numbers poverty, and in 2019 the percentage of poor population and number poor population has decreased to 3.35 percent (9.69 thousand poor population). Previous years can be seen from the table below:

Table 1. Development of Poor Population in Palangka Raya 2015-2019

\begin{tabular}{lcrrrr}
\hline Indicators of poverty & $\mathbf{2 0 1 5}$ & $\mathbf{2 0 1 6}$ & $\mathbf{2 0 1 7}$ & $\mathbf{2 0 1 8}$ & $\mathbf{2 0 1 9}$ \\
\hline Percentage of poor population (P0) & \multicolumn{1}{c}{$\begin{array}{c}(2) \\
\text { 3,91 }\end{array}$} & \multicolumn{1}{c}{3,75} & \multicolumn{1}{c}{3,62} & 3,47 & 3,35 \\
& 10,25 & 9,96 & 9,91 & 9,78 & 9,69 \\
\hline Poverty rates (Thousand People) & & & & & \\
\hline
\end{tabular}

Source: Susenas 2015-2019 (processed)

From the table above it can be explained further that:

1. Poverty Line (GK), Poverty Depth Index (P1), Poverty Severity Index (P2)

The poverty measurement method used by many countries including Indonesia relies on the expenditure approach known as the basic needs approach. Minimum basic needs are defined as financial measures in the form of money which include food needs that are equal to 2100 calories per capita per day plus non-food needs (clothing, housing, education, health and other basic needs) this is then referred to as the poverty line. Assessing poverty aside from the number and percentage of poor people, poverty dimension index and poverty severity index are also examined. The poverty depth index, also known as P1, illustrates the extent to which expenditure by poor people deviates from the poverty line. Meanwhile, the poverty severity index, known as P2, states the inequality of spending among the poor. The higher the depth and severity index values indicate increasingly serious poverty problems. 
Table 2. Poverty Indicator Development in Palangka Raya 2015-2019

\begin{tabular}{lccccc}
\hline Indicators of poverty & $\mathbf{2 0 1 5}$ & $\mathbf{2 0 1 6}$ & $\mathbf{2 0 1 7}$ & $\mathbf{2 0 1 8}$ & $\mathbf{2 0 1 9}$ \\
\multicolumn{1}{c}{$(1)$} & $(2)$ & $(3)$ & $(4)$ & $(5)$ & $(6)$ \\
\hline Depth Index (P1) & 0,51 & 0,41 & 0,51 & 0,63 & 0,43 \\
Severity Index (P2) & 0,11 & 0,06 & 0,14 & 0,21 & 0,09 \\
Poverty Line (Rp) & $\begin{array}{l}307796 \\
\text { Source: Susenas }\end{array}$ & $\begin{array}{l}324082 \\
\text { 2015-2019 }\end{array}$ & $\begin{array}{c}345417 \\
\text { (processed) }\end{array}$ & 353853 & 379420
\end{tabular}

In addition, if seen from the Palangka Raya poverty line in 2018, it increased by 2.44 percent to $\operatorname{Rp} 353,853$. In 2019 the poverty line will increase by 7.23 percent to $\operatorname{Rp} 379,420$. Ideally, the increase in the poverty line needs to be balanced with an increase in per capita income of the population. If this does not occur, then the percentage of the number of poor people will increase. Between 2015 and 2019 the poverty line always increased, but the percentage of the poor population and the number of poor people continued to decline. So, the increase in the poverty line is still offset by an increase in the average income per capita of the community.

The poverty depth index (P1) is an average measure of the expenditure gap of each poor population against the poverty line. During the 2015-2018 periods P1 experienced fluctuations, where the 2019 value was 0.43, the smaller P1 value in 2019 shows that the average expenditure of the poor population towards the poverty line is getting closer.

The poverty severity index (P2) illustrates the distribution of expenditure among the poor. P2 in 2019 is also getting smaller than in 2018, from 0.21 percent to 0.09 percent. Overall it can be concluded that the poverty conditions in Palangka Raya in 2019 are getting better when compared to 2018. This is indicated by the average income (approached by expenditure) of the poor moving closer to the poverty line and income gap (approached by expenditure) between poor population is getting smaller.

\subsection{Small and Medium Industries (SMIs)}

Small and Medium Industries (SMIs) is interpreted as a business field that has a distinctive nature and is generally a place for independent and growing businesses in the community. According to the Central Statistics Agency (2012) SMIs are Small and Medium Industries (IKM) as follows:

1) Small industry, which is an economic activity that carries out activities to convert basic goods into finished / half-finished goods and or goods of less value to higher-value goods, which have a workforce of 5-19 people.

2) Medium industry, which is an economic activity that carries out activities of converting basic goods into finished / half-finished goods and or goods of less value to goods of higher value, which have a total workforce of 20-99 people.

Meanwhile, according to Law No.20 of 2008 concerning Micro, Small and Medium Enterprises, Small and Medium Industries (IKM) as follows:

1) Small industry is an economic activity that processes raw materials, semi-finished materials and or finished goods become higher goods for their use and have an investment value of between Rp. 5,000,000 (five million rupiah) to Rp. 200,000,000 excluding land and business buildings.

2) Medium industry is an economic activity that processes raw materials, semi-finished materials and or finished goods higher goods for their use which have investment between Rp. 200,000,000 to 10 billion, excluding land and business premises. 
In the daily Republika.co.id (Sunday 21 Jul 2019) mentioned the difference between SMEs and SMIs, Small and Medium Enterprises or SMEs is a business that performs activities in the form of reselling various types of products produced by SMIs or Small and Medium Industries . Like the Small store to large stalls. In addition, SMEs usually carry out activities in the field of services such as laundry, repair of electronic equipment, machinery and so on while SMIs is a business that produces various types of products that are used in various needs of the activities of living things or others. If someone has direct production and marketing activities, they can be referred to as SMEs and SMIs. SMIs products will be well supplied if SMEs are supported by a variety of ease of distribution system techniques carried out by the SMEs together with SMIs. Without SME entrepreneurs, SMIs will find it difficult to supply production from the industries they run. One of the students' researches found the following facts as a differentiator between SMEs and SMIs.

Small business

Wealth: Rp. 50 million - Rp. 500 million

Results: IDR 300 million - IDR 2 billion

Small industry

Wealth: Up to Rp. 200 million

Results: Less than Rp1 billion

Medium Business

Wealth: Rp500 million - Rp10 billion

Results: Rp2 billion - Rp50 billion

Medium Industry

Wealth: 200 million - Rp10 billion

Results: Rp1 billion - Rp50 billion

As an economic milestone in Indonesia is closely related to the existence of SMIs, therefore by Berry, A., Rodriquez, E. \& Sandeem, H. (2001) in Lestari (2010) mentioned there are three reasons why the existence of SMIs is needed first, the performance of SMIs tend to be better at producing productive labor. Second, SMIs often increase their productivity through investment and actively follow technological changes. Third, SMIs are believed to have advantages in flexibility compared to large businesses. Then in another section, at least there are three advantages of SMIs that are not found in corporations, namely (1) small business capital. This small capital factor is the reason why many dare to take risks to start a business in this sector. (2) Capital is relatively small and does not involve many people so that its management can be done by improvising in choosing products and how to produce them. (3) The small capital and its improvisation turn out to be characteristic of SMIs as a very flexible business organization. Small businesses and household businesses in Indonesia also play an important role in absorbing labor, increasing the number of business units and supporting household income.

\section{Discussion}

There is a link between the SMIs sector and the level of employment, moreover this sector is considered as one of the sectors that is able to prevent unemployment and alleviate poverty, as part of the focus of this study along with data on the number of SMIs in the city of Palangka Raya: 
Table 3. Data of Palangkaraya Small and Medium Industry until July 2019

\begin{tabular}{|c|l|c|c|c|c|c|}
\hline No & $\begin{array}{c}\text { Types Of } \\
\text { Industries }\end{array}$ & $\begin{array}{c}\text { Total Business } \\
\text { Units }\end{array}$ & $\begin{array}{c}\text { Labor } \\
(\text { People) }\end{array}$ & $\begin{array}{c}\text { Investment } \\
\text { Value (Rp,000) }\end{array}$ & $\begin{array}{c}\text { Production } \\
\text { Value (Rp,000) }\end{array}$ & $\begin{array}{c}\text { Production } \\
\text { Value (Rp,000) }\end{array}$ \\
\hline 1. & Food & 972 & 972 & $5,898,626$ & $40,812,281$ & $6,447,366$ \\
\hline 2. & Clothing & 424 & 424 & $3,618,875$ & $28,836,350$ & $7,638,550$ \\
\hline & $\begin{array}{l}\text { Chemical And } \\
\text { Building } \\
\text { Material } \\
\text { Components }\end{array}$ & 1,702 & 1,702 & $36,758,936$ & $132,136,266$ & $29,590,496$ \\
\hline & $\begin{array}{l}\text { MMEI (Metal, } \\
\text { Machinery \& } \\
\text { Electronics } \\
\text { Industry) }\end{array}$ & 842 & 842 & $17,624,410$ & $37,185,666$ & $9,016,877$ \\
\hline 5. & Craft & 371 & 371 & $1,693,853$ & $3,875,132$ & 370,973 \\
\hline & Amount & 1,895 & 4,311 & $65,594,700$ & $242,845,695$ & $53,064,262$ \\
\hline
\end{tabular}

Resource: Dinas Perindustrian dan Perdagangan Kota Palangka Raya, 2020

From the data above it can be seen that from the five criteria developed as SMIs in the city of Palangka Raya, it is sufficiently developed with a total number of business units of 1,895 , then the number of workers that can be absorbed is 4,311 people. As for the total investment value of Rp. 65,594,700 and then followed by the production value of $\mathrm{Rp}$. $242,845,695$ and BB / BP value of Rp. 53,064,262.

The data above is data that can be said under normal conditions, before the occurrence of the Covid-19 pandemic and until now there has been no data recorded whether it has increased or decreased or even stagnant. In this study, it can be seen that the impact of the Covid-19 pandemic in terms of SMIs in Palangkaraya City that can make the potential increase in poverty rate greatly influences. The ten key informants interviewed were based on timber, rattan, accessories, food (culinary), traditional hat tailors (sumping and lawung), craft creations, traditional medicine (herbs), dayak coffee, herbal teas.

All key informants interviewed almost all answered that they were affected by a pandemic marked by the lack of sales of the products they produce. If it refers to the normal conditions before the pandemic orders the products they produce can meet the necessities of life, and some SMIs instead absorb labor, but this time they can no longer hire employees.

In addition, there are also SMIs that try to switch businesses in accordance with current conditions, for example, sewing masks, but still not optimal because it is not their usual line of business so far, this is also related to other competitors who also make health products (masks) that make marketing endurance (consistency) is hampered. There is one SMIs from the food sector (culinary) which actually experienced an increase in sales because the products that were sold were left at outlets at Hypermart, then when traced also these SMIs were observant in exploiting the situation because their products were ready-to-eat and readyto-eat food products such as fish floss, this strategy actually becomes an opportunity for other SMIs.

On the other hand, SMIs have installments in banks and cooperatives that make them more affected. Income, which can usually be used to pay for production costs, becomes nonexistent and is added to the installment costs, which at the beginning of borrowing are used as business capital. Looking at the various responses given by key informants, it can be seen that there is actually a vulnerability that leads to hidden poverty which slowly but surely can increase poverty in the future. Vulnerability as a result of this can make SMIs or in a broader context is the community experiencing powerlessness. In this situation by Billah (2003) in 
Warsono et al (2011) that the dimensions of poverty include four main points, namely: lack of opportunity, lack of ability, lack of security and powerlessness.

This is then when looking at poverty conditions, the review of the alleviation program also varies, including the Covid 19 pandemic condition which continues to hamper the movement of business actors (the community). Some government policies to reduce the number of sufferers of Covid 19 actually make businesses affected, for example by the existence of Large-Scale Social Restrictions (PSBB) that limit crowding citizens, this then has an impact on decreasing purchasing power.

To make matters worse, there is another side that will also be the impact of this pandemic if it is linked to SMIs and poverty, namely there will be a surge in unemployment. According to Budhi in Sirait and Marhaeni (2013) any country in the world that is categorized as a developed or developing country is always facing unemployment, the difference is that developing countries are unable to provide benefits to unemployed citizens, whereas developed countries are able to provide that guarantee.

In other words there is a surge in underemployment when the Covid 19 pandemic ends, unemployment by Sukirno (2006) in Hartanto and Masjkuri (2017) states that unemployment can be classified based on its characteristics, namely: 1. Hidden Unemployment, can occur if the addition of labor is done does not produce significant additions to the level of production. 2. Seasonal Unemployment, due to seasonal changes, usually occurs in the fisheries and agriculture sectors. 3. Half unemployed, occurs due to migration from rural to urban areas so rapidly that not all people get jobs easily, some are unemployed full time, some are not unemployed but also do not work full time and their working hours are much lower than those that are normal. They might only work one to two days a week. 4. Open unemployment, occurs because of the increase in job vacancies that are lower than the increase in workforce, as a result in the economy the more number of workers who cannot find work.

Comprehensive review is needed when looking at the problem of new poverty potential in the city of Palangka Raya at the time of the Covid pandemic 19. When this situation then becomes normal or in current terms new normal can actually be understood as a new form of adaptation for the community. For example all aspects of community activities must comply with health protocols. The impact of the Covid 19 pandemic also provides a condition where when returning all the normal things in the context of SMIs, it will certainly take years, or will lead to many new models (strategies) in developing a business.

\section{Conclusion}

Covid 19 Pandemic has had an impact on all areas of global community life including SMIs in the city of Palangka Raya. There are things to look out for when this pandemic turns out to have the potential to increase poverty levels coupled with the amount of unemployment that will also increase. The affected SMIs actors must have a strategy so that the businesses that are run continue to produce, because for the Indonesian people the role of the SMIs is seen as supporting the local economy that can be relied upon in absorbing labor and as a business that is able to meet the living needs of the SMIs actors themselves. 


\section{References}

Amal, B. K.2018. The Exploring of Marxism Regarding The Poverty Sustainability in Kampung Nelayan Seberang, Belawan, Indonesia. Budapest International Research and Critics Institute-Journal (BIRCI-Journal) (1): 79-92.

Badan Pusat Statistik (BPS), Statistik Indonesia 2012 (Statistical Yearbook Of Indonesia2012), (Jakarta : Badan Pusat Statistik (BPS).

Badan Pusat Statistik Kota Palangka Raya. 2019. Indikator Kesejahteraan Rakyat Kota Palangka Raya 2019. Cv Azka Putra Pratama. Palangka Raya.

Baidhawy, Zakiyuddin .2015. Kemiskinan dan Kritik Atas Globalisme Neo-Liberal. LP2MPress, Institut Agama Islam Negeri (IAIN) Salatiga. Salatiga.

Berry, A., Rodriquez, E. \& Sandeem, H. (2001). Small and medium enterprises dynamics in Indonesia. Bulletin of Indonesian Economic Studies 37 (3).

Dokumen Dinas Perindustrian dan Perdagangan kota Palangka Raya. Data Industri Kecil dan Menengah Kota Palangka Raya S/D Bulan Juli Tahun 2019.

Harahap, E. S., Maipita, I., and Rahmadana M. F. Determinant Analysis of Education Inequalities in Indonesia. Budapest International Research and Critics Institute-Journal (BIRCI-Journal) (3): 1067-1082.

Hartanto , Budi, T., Masjkuri, and Umajah, S.2017. Analisis Pengaruh Jumlah Penduduk, Pendidikan, Upah Minimum dan Produk Domestik Regional Bruto (Pdrb) terhadap Jumlah Pengangguran di Kabupaten dan Kotaprovinsi Jawa Timur Tahun 2010-2014. Jurnal Ilmu Ekonomi Terapan. Juni 2017; 02(1): 21-30 Issn 2541-1470.

Idrus, Muhammad.2009. Metode Penelitian Ilmu Sosial-Pendekatan Kualitatif dan Kuantitatif (Edisi Kedua). Erlangga. Jakarta.

Lestari, Puji, E. Penguatan Ekonomi Industri Kecil Dan Menengah Melalui Platform Klaster Industri. Vol. 6 No. 2 (2010).

http://jurnal.ut.ac.id/index.php/JOM/article/view/289. Diakses 05 Juni 2020. Pukul 14.01 WIB.

Lubis, R., Phill, I. A., and Baiduri, R. Survival Strategy for Lokan Seekers in Paya Pasir Village, Kec. Marelan, Medan, Indonesia. Budapest International Research and Critics Institute-Journal (BIRCI-Journal) (2): 293-303.

Martinelli, I., Harahap, A., Zainuddin. Community Economic Development Prospect Based on Wakaf Funds. Budapest International Research and Critics Institute-Journal(BIRCIJournal) (2): 409-423

Moleong, Lexy, J.2007. Metodologi Penelitian Kualitatif, Penerbit PT Remaja Rosdakarya. Offset. Bandung.

Sirait, Novlin dan A.A.I.N Marhaeni. 2013. Analisis Beberapa Faktor Yang Berpengaruh Terhadap Jumlah Pengangguran Kabupaten/Kota Di Provinsi Bali. E-Jurnal EP Unud, 2 [2] : 108-118. ISSN: 2303-0178.

Sugiyono.2008. Metode Penelitian Kunatitatif Kualitatif dan R\&D. Alfabeta. Bandung.

Undang-undang No.20 Tahun 2008 tentang Usaha Mikro, Kecil, dan Menengah

Warsono, Hardi dkk. Kajian Kebijakan Sosial (Kajian Tentang Kebijakan Pendidikan (BOS), Kesehatan (JAMKESMAS) dan Perlindungan Anak di Jawa Tengah dan Jawa Timur. UNICEF Semarang.

https://jeo.kompas.com/bersiap-tameng-ekonomi-untuk-dampak-wabah-corona， Senin, 23 Maret 2020 diakses 5 Juni 2020 pukul 13:34 WIB

https://republika.co.id/berita/pux1g1/apa-perbedaan-ikm-dan-ukm "Apa Perbedaan IKM dan UKM? “" Ahad 21 Jul 2019, diakses 05 Juni 2020 pukul 03.03 WIB 